\title{
Impact of Using Flipped Classroom Strategy in Developing the Mathematical Thinking of Pre-Service Teachers in Open Education Systems in Jordan
}

\author{
https://doi.org/10.3991/ijet.v17i03.24973 \\ Bahjat Altakhayneh \\ Arab Open University, Amman, Jordan \\ B_takahyneh@aou.edu.jo
}

\begin{abstract}
This study aimed to investigate the impact of the use of the flipped classroom strategy in developing the mathematical thinking of preservice teachers in the Faculty of Education in open education systems in Jordan. The sample of the study consisted of students enrolled in the program of educational studies for the year 2019/2020 in the open education systems. To achieve the objectives of the study, the validity and reliability of a mathematical thinking test was verified. The methodology of the study was used in a quasiexperimental design, and the results of the study showed statistically significant differences between arithmetic means of mathematical thinking $(\alpha=0.05)$ in favor of the post mathematical thinking test and showed no statistically significant difference $(\alpha=0.05)$ between the arithmetic means of the employee in the field of education and non-employee in mathematical thinking.
\end{abstract}

Keywords—flipped classroom, mathematical thinking, open education

\section{Introduction}

In recent years, developments in educational technology have emerged, represented in the employment of computer and mobile applications in various areas of life, and they have led to a change in the teaching strategies and methods used, the styles of education, and the qualifying and training of pre-service teachers on strategies commensurate with these changes.

As a result of rapid developments of information and communication technology and needs for applying distance learning, there are many calls worldwide to use new strategies for teaching and training pre-service teachers which they receive in open learning, in terms of providing an appropriate environment conducive to acquiring 21 st century skills [1].

Open Education Systems (OES) in higher education provide interactive teaching strategies to help learners think and acquire requirements of this new era, and to meet the needs of society, and to qualify individuals to face the challenges of the changing era[2]. 
Nationally, the OES tries in a continuous manner to develop the curricula to face the new challenges by providing teachers and students with learning platforms, activities, resources, and new strategies to reduce time and effort [3].

In OES the programs provide $25 \%$ of credit hours as face to face lectures and $75 \%$ as synchronized and non-synchronized activities in the learning management systems (LMS) which provides two types of tasks:

Resources: Provides resources to support student learning. It includes books, files, folders, abstracts, worksheets, page modules, and IMS content packages. The resources provide students with information, skills, lessons, and problem solving.

Activities: Tasks that the learner has to perform such as submitting assignments, quizzes, attendance, lessons, questionnaires, feedback activity, glossary, forums, chat, BigBlueButon (https://lms.arabou.edu.kw/jordan).

In OES, curricula are prepared through the Learning Management System (LMS) and depend on hybridizing the face to face education system with distance learning in a technological environment to provide educational programs and activities for developing the learner's capabilities in critical and creative thinking.

Mathematical Thinking (MT) skills are considered as one of the most important learning outcomes of pre-service teachers in Jordan, where the pre-service teachers acquire the skills of inductive, deductive, symbolizing, modeling, proofing, criticism, analyzing, and interpretation [4].

The MT skills are very important for pre-service teachers to apply educational experiences in real life problems and to relate mathematics with other subjects [5].

The ability to think mathematically and to use MT to solve problems is an important goal of schooling. In this respect, MT will support science, technology, economic life and development in an economy. Increasingly, governments are recognizing that economic well-being in a country is underpinned by strong levels of what has come to be called 'mathematical literacy' in the population [6].

Mathematics curricula provide a fertile environment to develop MT through developing the ability of students to solve problems, increasing the motivation of students, and increasing the role of students in learning mathematics [5].

Training and qualifying mathematics teachers before service is very important to develop their capacity of thinking and to acquire MT through using modern strategies [7].

Based on the above, it is necessary to pay attention to the development of MT among pre-service teachers, and to provide educational strategies that help in developing MT, by increasing the opportunity for learning for them and by training them in MT skills, solving mathematical problems, and the use of qualitative strategies in a changing era[3].

In view of the emergence of modern learning styles in higher education, such as the style of distance education, and the emergence of strategies commensurate with the technology, it was necessary to search for new educational strategies that provide experiences and activities of OES, such as FCS, virtual classes, educational platforms, and interactive software.

Flipped classroom strategy (FCS) is considered one of the most suitable strategies for facing the challenges of distance learning since it can offer merging technology 
with teaching [8]. The principle of FCS is to prepare the materials of lessons firstly, and to change the roles of teachers and students.

The teacher's role of FCS is to prepare videos, abstracts, voices, and worksheets, to increase learners' interaction before attending the face to face lectures, and to acquire the important skills and information. In the face to face lectures, the teacher provides students with feedback about their progress in the course, so the classrooms became the place for discussion and solving problems [9]. The FCS is a style of learning through which the traditional role played by the university and the home is changed, so that each takes the place of the other, as the traditional lecture is converted through the FCS using the available and appropriate technology into recorded lectures that are placed on the learning management website (LMS) so that the student can access it anytime and anywhere, then he comes to the university to discuss, solve worksheets, apply information, master skills, and solve problems [10].

Teaching mathematics courses at universities which adopted open learning requires more class time for students to acquire the concepts, skills and its applications, so it is very important to provide all content elements. In an FCS classroom strategy, the learners will watch the lectures at home, before the time of the lecture, and then at the time of the lecture they will review the problems through discussions, dialogues, and solving worksheets [11]. 2018).

FCS is very important because it allows time for teachers to solve students' problems by answering students' questions instead of focusing on providing the content; the lecture can be repeated more than once because it is recorded in the form of videos. FCS gives teachers more freedom to determine the amount of time they spend with each student, and it provides more transparency for parents and increases opportunities for communication with students and their parents [12].

To apply the FCS in universities which adopted open learning styles requires four major pillars:

1. Flexible environment: The FCS allows for providing a variety of learning methods and the teacher may need to constantly rearrange the classroom environment to suit the lessons or subjects, so the students are able to choose when and where to learn.

2. Shift in the learning culture: Teachers define the content to be taught in a lecture and the content students are required to discover on their own, and teachers use the intended content to increase teaching time by using a variety of learning methods such as active learning and problem solving.

3. Intentional content: In the FCS, an intentional shift takes place from the teachercentered class to the learner-centered class, and the learner actively participates in the process of forming knowledge through the opportunities available to them.

4. Professional teachers: Regarding FCS, the need increases for trained teachers in FCS to accept constructive criticism and receive immediate and delayed feedback [13].

Amber et al. [14] suggested steps to implement the FCS as follows: determining the aims of lessons, selection of the content, choice of the technology style, choice of tasks, preparation of the content in digital form, determination of the activities, and finally the digital evaluation. 
Alahmadi [9] refers to the stages of implementation of FCS as follows:

1. Determine the topic to be taught by the FCS.

2. Analyze the content of the topic into values, knowledge, skills, concepts, facts, and problem solving.

3. Define a description of the educational video, including image, sound and text with a duration not exceeding ten minutes.

4. Send the video to students through the students' LMS, directing them to watch it.

5. Apply knowledge students learned through videos in interactive activities within the classroom.

6. Student learning evaluation (formative, final).

The learning strategy using the FCS is implemented by motivating the learner to self-learning, active learning, and using inquiry and differentiated education [11].

Many studies are interested in FCS in teaching such as Olakanmi's [15] study which aimed to investigate effects of FCS of instruction on academic performance and attitudes of 66 first-year secondary school students towards chemistry. Findings from this study revealed that the FCS facilitated a shift in students' conceptual understanding of the rate of chemical reaction significantly more than the control group. Positive significant differences were found on all assessments with the FCS students performing higher on average. The findings of the study also support the notion that teachers should be trained or retrained on how to incorporate the FCS into their teaching and learning processes because it encourages students to be directly involved and active in the learning.

Alhosneeh [16] conducted a study aimed at investigating the effects of developing general self-efficacy and academic achievement of the science subject among ninth grade female students in the Sultanate of Oman. The sample of the study consisted of 53 female students, the findings of the study showed that there are differences between the experimental and control group in both the self-efficacy scale and the achievement test in favor of the experimental group (which was trained by FCS). Through the researcher's experience in applying the FCS, she found that it had several benefits the most important of which are that it enhances self-learning, contributes to raising the level of motivation towards learning, and also provides students with social communication skills by applying cooperative learning in the classroom when solving activities and exercises.

Khalil [17] conducted an action research study aimed at investigating the effects of FCS in developing some self-organized learning skills and the tendency toward mathematics among sixth graders of elementary school. The number of sample members was 18 students divided equitably into two experimental groups taught using FCS and a control group taught by traditional methods. The study lasted three weeks and included eight lessons from the unit "Operations on Ordinary Fractions," and the results of the study showed that the level of the students' self-organized learning components came in descending order: academic motivation, self-monitoring, and strategy adaptation. The strategy also positively affected the attitude towards mathematics among the students of the experimental group. 
Aldowekh [18] conducted a study to investigate the effects of FCS in teaching computer courses on self-learning skills in Jubail City in Saudi Arabia. The results of the study revealed that self-learning skills for female students increased in the experimental group which was taught by FCS, and the FCS contributed to taking into account individual differences in the students' learning according to their abilities, and it contributed to increasing their motivation. Also, the results showed that most of the students demonstrated their responsibility for self-learning of lessons without relying on the teacher, with most students supporting the use and application of the FCS in education.

DeCrazia et al. [19] conducted a study for university students, by studying the effect of the FCS on students' readiness during the time of formal lectures. The results of the study showed that students during the application of this strategy were more prepared and more understanding during the time of formal lectures.

Wagner et al. [20] conducted a study to investigate the effectiveness of applying the FCS to electronic engineering students at the University of Regina in Canada. The results of the study showed that students were more motivated to learn and more receptive and understanding of the topics at hand.

Mason et al. [21] conducted a study to compare students' performance and their perceptions about teaching using the FCS. The results of the study showed that the FCS encouraged students to practice problem-solving skills individually and collectively, and students were more satisfied and interactive with the topics raised compared to the students that used traditional strategies.

Davies et al. [22] conducted a study to investigate the benefits of FCS, students' satisfaction with this method, and to compare it with traditional strategies. The results of the study showed that the FCS facilitated students' learning processes, making them more motivated, effective, and more individual to adapt to their special needs. The study of Butt [23] also supported the effectiveness of the FCS in increasing the trend towards learning using the FCS among Australian university students.

Hazaymeh \& Altakhaineh [24] conducted a study investigating the effect of FCS on developing Emirati English Forgone Language learners' pragmatic competence. It compares FCS with the conventional method of developing learners' request speech acts. The results showed that FCS was more effective than the other method in raising the level of pragmatic competence among the participants. Also, the results of the study revealed that the participants' performance-on-request speech acts in the treatment group remarkably improved in the post-test, because they had a more flexible and accessible e-learning environment, which in turn, enhanced their pragmatic competence after the treatment.

Sabag et al. [25] conducted a study aimed to design a proposed model of a flipped classroom based on projects. In addition, they investigated its effectiveness in developing educational software production skills for students of the Faculty of Education at the Islamic University of Gaza. The results of the study revealed that there were statistically significant differences between the means of the female students' degrees in the pre and post application of the observation card in favor of the post application.

Dweikat \& Raba [26] conducted a study to investigate the perceptions of EFL teachers of the FCS in the Palestinian context. The sample of the study consisted of 
79 EFL teachers participating in the Teacher Education Improvement Project (TEIP)Additional Financing in Palestine. The quantitative results showed that the total degree of teachers' responses was (3.85) which suggested a high level of perceptions. The results of the study also revealed three major themes with regard to teachers' perceptions and that teachers were somehow divided into two groups: the first group was in favor of using the flipped learning model but with mature students and after providing the required infrastructure, and the second group was not in favor of using the flipped learning model because it might add more responsibilities and tasks to the overloaded teachers and it might distract students as well.

Roasa [27] conducted a study aimed at identifying the effectiveness of the FCS in teaching the science teaching strategies and its assessment course on the academic achievement and mind habits developed by the students of Princess Norah bent Abdurrahman University. The sample of the study consisted of 81 students chosen from Princess Norah bint Abdulrahman University in Saudi Arabia. The results showed that supreme of the experimental group which used FCS in achievement, but no differences between experimental and control group in habits of mind.

In the field of Mathematical Thinking (MT), Algaysi [28] conducted a study that aimed to investigate the effectiveness of the Marazzano learning model in MT and the attitudes towards mathematics among students of the primary stage in Tafila City in Jordan. Results of the study showed the superiority of the experimental group which was taught by Marazzano's learning model over the control group which was taught by conventional method in both MT and the attitudes towards mathematics.

Fernandez [29] also conducted a study aimed at describing students' MT and its relationship to solving mathematical problems. It used the descriptive method, questionnaires, and interviews with students. The results of the study showed that the training programs for MT contribute to developing students' thinking and helps them with flexibility in thinking, achievement, and the ability to solve mathematical problems.

Ersoy \& Ganer [30] conducted a study aimed at investigating the influence of problem solving on a specific topic in mathematics to improve mathematical problemsolving and teaching skills, and its relationship to MT for students in the United States of America. The results indicated that solving the problem for a specific topic has a positive impact on MT as students are able to choose and strategically practice their skills and abilities.

Barham and Al-Khatib [31] conducted a study to investigate levels of MT skills among students of a teacher's class at the Hashemite University and the relationship to students' achievement in mathematics. The results of the study also showed a correlation between MT and achievement.

Risig [32] conducted a study to investigate the impact of real learning on developing MT skills among middle school students in Makkah Al-Mukarramah. The results of the study showed the superiority of the experimental group that used real learning over the control group that did not use real learning in all MT skills (induction, deduction, symbolism, logic, and mathematical proof), and the need to train teachers on real learning strategy. 
Aprianto et al. [33] study aims to investigate the use of multimedia- assisted learning in a flipped classroom for fostering the students' autonomous learning at EFL University, the finding of this study showed that a flipped classroom by using multimedia-assisted learning helps the students stimulate their autonomous learning because the students feel free to explore their creativity through an independent learning atmosphere without any tension.

Zaroug et al. [34] e authors examined the impact of the proposed approach on various facets of students' SRL, including motivational beliefs, self-regulation strategies, and collaborative strategies, the findings indicated that students who actively engaged within flipped PBL activities demonstrated increases in cognitive and metacognitive functioning both individually and collaboratively, moreover the participants also claimed that the approach was useful and effective.

Alsalhi et al. [35] study aimed at investigating the influence of blended learning on the academic performance of students of a statistics Bluman course at the University of Ajman, the findings indicated significant statistical differences among the mean scores on the students' post-test in the two study groups. This is in favor of experimental group, educated using blended learning. Furthermore, in the results, the scores of the experimental group students were diverse based on the variable of gender (in favor of females), and according to the students' academic year (supporting those students in the fourth academic year). However, there were no statistically significant differences among the students according to the variable of the college in which they studied.

The current study attempts to investigate the effect of using the FCS on developing MT among pre-service teachers in OES.

\subsection{Problem of the study}

The emergence of recent trends in university education such as OES and distance learning requires a review of the teaching strategies used, especially in the era of the mobile and computerized application revolution. Traditional education strategies no longer meet the purpose and achieve the desired educational goals [1].

It is imperative to provide educational strategies that are compatible with open education systems based on the integration of modern technologies with educational platforms and LMS in order to provide suitable educational environments, save time and effort, and increase students' motivation to learn.

In pre-service teacher preparation, it is imperative to train pre-service teachers on educational strategies commensurate with the requirements of this age, increase opportunities for active learning for students, provide various and multiple resources, increase self-learning opportunities, and invest mobile programs and applications in education.

The Covid-19 pandemic affects teaching strategies worldwide and in Jordanian universities, so the teaching and learning style must change according to requirements of the modern era.

The study's problem is represented in an attempt to investigate the impact of using the FCS on developing MT among pre-service teachers in OES in Jordan and its rela- 
tionship to the nature of the pre-service teachers (employee in the field of education / non-employee).

\subsection{Questions of the study}

1. What is the effect of using the FCS on developing MT among pre-service teachers in OES in Jordan?

2. Does the MT of pre-service teachers in OES differ according to the type of preservice teachers (employee in the field of education / non-employee)?

\subsection{Terminology of the study}

Flipped Classroom Strategy (FCS). The set of procedures that the teacher undertakes in order to achieve educational aims, and in this strategy the procedures are represented in employing modern technology in a way that suits the needs of students. The strategy consists of the following stages:

1. Determining the topic to be taught: It includes defining (objectives, activities, prerequisites, characteristics of the target group).

2. Analyzing the topic contents which include aims, activities, pre-requests, and characteristics of the target group.

3. Preparing digital content related with the topic (videos, voices, abstracts, worksheets, quizzes, final exams).

4. Deliver the materials via LMS and orient the students to watch videos and solve activities.

5. Applying the information in classrooms and solving advance worksheets.

6. Formative and final evaluation.

Mathematical Thinking (MT). A mental activity performed by the learner when exposed to a stimulus related to mathematics topics. It includes the following mathematical thinking skills: induction, deduction, symbolism, guessing, reasoning, modeling, prediction.

Open Education Systems (OES). They are educational institutions that blend the use of classroom meetings (direct and indirect) and educational platforms on internet applications. They provide computerized and non-computerized educational resources with no limitation on age, gender, or nationality.

Learning Management System (LMS). A platform used in communication with students that provides materials, activities, resources.

\section{$1.4 \quad$ Importance of the study}

Methods of teaching mathematics is considered one of the essential competencies of pre-service teachers to apply the skills of teaching mathematics actively and increase the role of students at elementary stages. 
In OES, students are independent in their learning and it is important to provide educational resources that help save more time. The FCS provides educational materials and worksheets in advance and in face-to-face meetings, discussions, and dialogue about students' solutions and feedback is provided to them.

The FCS is a recent trend in education in general and in particular in OES, because it develops independence in learning, self-learning skills, and students gain important study behaviors and habits [12].

This study provides a theoretical framework on the FCS through educational platforms (Moodle) and the application of this strategy to pre-service teachers to increase their ability to think mathematically and solve problems.

This study provides an important tool in MT, as MT is one of the goals of educational programs for pre-service teachers in order for them to acquire MT skills and employ them in the field of teaching elementary school students.

Regarding the relationship between the FCS and MT, it is noted that the FCS provides activities related to mathematics teaching methods such as induction, deduction, prediction, reasoning, and mathematical proof through the LMS.

\subsection{Limitations of the study}

The study is limited to:

- Mathematics teaching methods course at OES in Jordan for the academic year 2019/ 2020.

- Applying FCS through Learning Management System.

- Mathematical thinking skills: induction, deduction, symbolism, guessing, reasoning, modeling, prediction.

\section{Methodology}

A quasi-experimental approach was used within two groups, with experimental and control groups, where results were processed by way of comparing experimental marks with the control marks of the sample.

The statistical tools used were the arithmetic means, standard deviations, and the $\mathrm{t}-$ test within the experimental and control group.

\subsection{Study subjects}

The sample of the study consisted of students of the Faculty of Education during the 2019/2020 academic year, enrolled in the "mathematics teaching methods" courses. The sample consisted of 85 students, distributed according to the nature of previous employment in the field, as seen in Table 1. 
Paper-Impact of Using Flipped Classroom Strategy in Developing the Mathematical Thinking of...

Table 1. Distribution of study members in courses and according to previous work experience

\begin{tabular}{|l|c|c|c|}
\hline \multicolumn{1}{|c|}{ Nature of Work } & Employee in the Field of Education & Non-Employee & Total \\
\hline No. & 40 & 45 & 85 \\
\hline
\end{tabular}

\subsection{Tools of the study}

Flipped classroom strategy. This strategy aims to increase the chances of student engagement before giving the lecture, effectively increasing the time allotted for study. Educational content was prepared in the flipped classroom using the following procedure:

- Identify the title of the lesson or lecture and identify the objectives of the topic, activities, and previous requirements.

- Analyze the topic-specific cognitive content that will be taught- the concepts, generalizations, skills, and issues.

- Prepare educational content:

1. A PowerPoint presentation as an explanatory reference point, to pointedly lay out what is to be taught and specifically present its objectives.

2. A video tutorial ( $\sim 15$ minutes) made using Camtasia software.

3. Educational activity area: Allocating a work room for the previous requirements.

4. A worksheet to be implemented in the class.

- Direct students to access the site of the learning department to watch the video in advance of the class lecture.

- In the classroom meeting, direct students to form homogeneous and heterogeneous groups to complete and discuss the solutions to the worksheet within the classroom.

- Deploy and implement a final worksheet on the LMS.

Moodle. The LMS, or learning management system (https://lms.arabou.edu.kw/ jordan), which serves to provide students with e-learning resources, is structured with links as follows:

Book, File, Folder, Integrated Content (LMS Content Package), Label, Page, URL.

It also serves to provide students with various educational activities, such as assignments, workshops, lessons, short asynchronous tests or quizzes, short synchronous tests or offline quizzes, discussion boards, databases, feedback forum, glossary, external tools, and tool wiki.

What distinguishes the LMS is the ability to provide multiple and varied sources, such as summaries, publications, videos, and recordings. It also provides direct and indirect interaction through executing required duties, in the form of worksheets and simultaneous and asynchronous tests and provides immediate and deferred feedback.

Mathematical thinking test. A test in mathematical thinking has been developed from the content of the mathematics curriculum for students of the College of Education and aims to measure the extent to which the student has acquired mathematical thinking skills represented in induction, deduction, symbolism, guessing, reasoning, modeling, and prediction, and represented by the topics: Solving the problem Mathe- 
matics, strategies for teaching the elements of mathematical content, and models for learning and teaching mathematics.

Reliability of the mathematical thinking test. The reliability of the test was verified by using the reliability of the internal consistency of the cores of MT using the Cronbach alpha $(\alpha)$ method, and Table 2 shows the reliability parameters for each core of MT and overall reliability.

Table 2. Reliability coefficients for the cores of MT, and overall reliability

\begin{tabular}{|c|c|c|c|c|c|c|c|c|}
\hline $\begin{array}{c}\text { Core of Mathematical } \\
\text { Thinking }\end{array}$ & Induction & $\begin{array}{c}\text { Deduc- } \\
\text { tion }\end{array}$ & $\begin{array}{c}\text { Symbol- } \\
\text { ism }\end{array}$ & Guessing & Modeling & Reasoning & Perfection & Total \\
\hline Reliability Coefficient & 0.91 & 0.90 & 0.86 & 0.89 & 0.87 & 0.89 & 0.86 & 0.88 \\
\hline
\end{tabular}

It is noticed from Table 2 that the reliability coefficients for each cores of MT are high, as the overall reliability coefficient reached $(0.88)$, and thus the reliability coefficient is acceptable for the purposes of the current study.

Validity of the mathematical thinking test. Firstly: Content Validity: In order to verify the validity of the test, it was presented to a group of six qualified and experienced arbitrators in the field of methods of teaching mathematics to express an opinion on the test paragraphs and the degree of their affiliation. Some paragraphs were amended, and some were deleted in light of the referees 'notes, and the test items became 21 paragraphs in the final exam presentation.

Secondly: Construct Validity: To verify the validity of the construction of the test, it was applied to an exploratory sample of 35 male and female students (pre-service teachers) in open education systems, and the correlation coefficients were calculated for each core of mathematical thinking and the total score of the test, and Table 3 shows a matrix of correlation coefficients between the sub-axes of Mathematical Thinking and total score of the test.

Table 3. Matrix of correlation coefficients between the cores of mathematical reasoning and the total score of the tes

\begin{tabular}{|l|c|c|c|c|c|c|c|c|}
\hline \multicolumn{1}{|c|}{ Core } & Induction & Deduction & Symbolism & Guessing & Modeling & Reasoning & Prediction & Total \\
\hline Induction & 1 & 0.85 & 0.83 & 0.77 & 0.81 & 0.49 & 0.82 & $0.83^{*}$ \\
\hline Deduction & & 1 & 0.82 & 0.73 & 0.85 & 0.80 & 0.77 & $0.92^{*}$ \\
\hline Symbolism & & & 1 & 0.54 & 0.84 & 0.79 & 0.52 & $0.85^{*}$ \\
\hline Guessing & & & & 1 & 0.7 & 0.78 & 0.83 & $0.86^{*}$ \\
\hline Modeling & & & & & 1 & 0.86 & 0.79 & $0.82^{*}$ \\
\hline Reasoning & & & & & & 1 & 0.83 & $0.92^{*}$ \\
\hline Prediction & & & & & & & 1 & $0.89^{*}$ \\
\hline
\end{tabular}

* Significant at $\alpha=0.05$ level

It was noticed from Table 3 that the correlation coefficients of each core of MT with the total score of the test were high which indicated that the cores of MT participate in measuring the characteristic of MT. 


\subsection{Procedure followed}

- Looking into the theoretical framework behind the FCS, in terms of its principles, its procedures and steps to teaching with its use, and the software needed to implement it, such as the use of LMS and Camtasia software.

- Identifying the sample of the study and its characteristics along with some of the variables associated with it such as whether they have previous experience in the field of education and had prior training in teaching strategies.

- Preparing and equipping the Moodle LMS with the resources, activities, summaries, publications, and videos required for the FCS.

- Verifying the equivalence of the two study groups in the previous mathematical thinking, using a t-test in the mathematical thinking. The comparison was made between the arithmetic means of the experimental and control group, where the significance level was 0.24 , which indicates the equivalence of the two study groups in the previous mathematical thinking.

- Preparing the MT test, and verifying their validity and consistency.

- Implementing the FCS of teaching via the LMS and guiding students to best use this strategy's resources throughout the first semester of the 2019/2020 academic year.

- Following-up with students through the LMS and carrying out with course activities via the LMS as well as within classroom meetings.

- Extracting the results of the study using the Statistical Packet Program (SPSS).

- Discussing results and making recommendations and proposals.

\section{Results and discussion}

The current study aims to investigate the impact of the use of the FCS, via the Moodle LMS, on the mathematical thinking of pre-service teachers at the Faculty of Education of a university that employs an OES. The study posed two questions, which I will discuss separately here.

\subsection{First study question}

1. What is the effect of using the FCS on developing MT among pre-service teachers in OES in Jordan?

To answer this question, the arithmetic means, standard deviation, for both experimental and control groups of MT and t-test values were calculated as seen in Table 4. 
Paper - Impact of Using Flipped Classroom Strategy in Developing the Mathematical Thinking of...

Table 4. Results of t-test analysis for the significance of the differences between the arithmetic means of pre-service teachers in the experimental and control groups of (MT)

\begin{tabular}{|c|c|c|c|c|c|c|c|}
\hline \multirow[b]{2}{*}{ Core } & \multirow[b]{2}{*}{ No. } & \multicolumn{2}{|c|}{ Control } & \multicolumn{2}{|c|}{ Experimental } & \multirow[b]{2}{*}{ T-value } & \multirow[b]{2}{*}{ Sig. } \\
\hline & & Arithmetic Mean & $\begin{array}{l}\text { Standard } \\
\text { Deviation }\end{array}$ & $\begin{array}{l}\text { Arithmetic } \\
\text { Mean }\end{array}$ & $\begin{array}{l}\text { Standard } \\
\text { Deviation }\end{array}$ & & \\
\hline Induction & 85 & 7.3 & 1.6 & 10.2 & 2.0 & 10.5 & $0.00^{*}$ \\
\hline Deduction & 85 & 7.4 & 1.8 & 10.8 & 1.3 & 13.6 & $0.00^{*}$ \\
\hline Symbolism & 85 & 7.6 & 2.4 & 11.4 & 1.5 & 11.9 & $0.00^{*}$ \\
\hline Guessing & 85 & 7.8 & 1.8 & 11.5 & 1.1 & 16.5 & $0.00^{*}$ \\
\hline Modeling & 85 & 6.7 & 1.5 & 11.6 & 1.4 & 22.2 & $0.00^{*}$ \\
\hline Reasoning & 85 & 6.7 & 1.9 & 11.2 & 1.5 & 16.3 & $0.00^{*}$ \\
\hline Prediction & 85 & 7.6 & 2.4 & 10.2 & 2.0 & 7.8 & $0.00^{*}$ \\
\hline Total & 85 & 51.2 & 9.5 & 76.9 & 4.1 & 22.7 & $0.00^{*}$ \\
\hline
\end{tabular}

It is noticed from Table 4 that the arithmetic mean of mathematical thinking reached (76.9) of the experimental group, and the arithmetic mean of pre-service mathematical thinking reached (51.2) of the control group, with difference of (25.7). It is also noticed that there is a statistically significant difference $(\alpha=0.05)$ between the average grades of pre-service teachers in both the experimental and control groups of mathematical thinking with a significance level (0.000).

This indicates the effect of using the FCS on developing MT among pre-service teachers in OES in Jordan, and for each core of mathematical thinking, as students were able to master the skills and previous requirements, and the necessary time was saved with computerized and non-computerized activities.

The formative tests presented on the Learning Management website helped them increase their abilities and skills in mathematics. Students pointed out that the worksheets available on each unit supported their acquisition of knowledge of necessary concepts and skills, and the duties presented on the LMS gave them useful experience with which to complete the necessary tests and materials for learning.

The FCS is important in providing active learning and increasing students' learning motivation. The strategy is appropriate for blended learning in OES in terms of providing sources of support, and this is confirmed by the standards for mathematics education [5] in the necessity of providing a learner-centered learning environment, taking into account individual differences among students, and emphasizing the need to learn the previous requirements, and in this system of education is a percentage of students who have left school for a long time, and therefore it is necessary to review the most important necessary skills.

Ausebel theory [36] emphasized the necessity of presenting educational content in a meaningful way, and this is what distinguished this strategy in terms of providing activities in a sequential manner, from easy to difficult, providing the required duties, and providing feedback, whether immediate or postponed. The Learning Management website (Moodle) helped provide resources and support, be it summaries, brochures, dialogue through forums, discussions with course instructors, and with some of them, and the site also helped provide simultaneous and asynchronous educational activities, 
formative exams, classroom and homework assignments, resulting in increased motivation to learn and achieve success.

This result is consistent with the study of DeCrazia et al. [19]; Mason et al. [21]; Wagner et al. [20]; and Strayer [37] on the impact of using the FCS in teaching university courses.

\subsection{Second study question}

2. Does the MT of pre-service teachers in OES differ according to the type of preservice teachers (employee in the field of education / non-employee)?

Arithmetic averages, standard deviations, and t-tests were used to compare the arithmetic means in mathematical thinking between employees in the field of education and non-employees, and Table 5 explains that.

Table 5. T-test for the significance of the differences between employee and non-employee in MT, and in each of the cores of MT

\begin{tabular}{|c|c|c|c|c|c|c|c|c|}
\hline Nature of Work & Empl & ee in the $\mathrm{Fi}$ & of Education & & Non-Emp & oyee & & \\
\hline Induction & No. & $\begin{array}{c}\text { Arithmetic } \\
\text { mean }\end{array}$ & $\begin{array}{l}\text { Standard } \\
\text { deviation }\end{array}$ & No. & $\begin{array}{l}\text { Arithme- } \\
\text { tic mean }\end{array}$ & $\begin{array}{l}\text { Standard } \\
\text { deviation }\end{array}$ & T-Test & Sig \\
\hline Deduction & 48 & 10.3 & 2.0 & 45 & 10.1 & 2.0 & 0.77 & 0.424 \\
\hline Symbolism & 48 & 10.9 & 1.3 & 45 & 11.8 & 1.6 & 0.496 & 0.547 \\
\hline Guessing & 48 & 11.4 & 1.5 & 45 & 11.3 & 1.5 & 0.08 & 0.621 \\
\hline Modeling & 48 & 11.5 & 1.1 & 45 & 11.6 & 1.1 & 0.220 & 0.826 \\
\hline Reasoning & 48 & 11.6 & 1.5 & 45 & 11.6 & 1.4 & 0.081 & 0.935 \\
\hline Prediction & 48 & 11.0 & 1.6 & 45 & 11.0 & 1.5 & 0.008 & 0.993 \\
\hline Induction & 48 & 10.2 & 2.0 & 45 & 10.1 & 1.9 & 0.318 & 0.751 \\
\hline $\begin{array}{l}\text { Mathematical } \\
\text { Thinking }\end{array}$ & 48 & 77.9 & 3.94 & 45 & 76.5 & 4.15 & 0.80 & 0.426 \\
\hline
\end{tabular}

It is noticed from Table 5 that there is no statistically significant difference $(\alpha=$ $0.05)$ between the average means of employee and non-employee in MT, as the value of $t$ reached (0.80) and the level of significance $(0.426)$.

This indicates that the educational strategy affects the mathematical thinking of both pre-service teachers, employees in the field of education and non-employees.

This result indicates that regardless of the nature of pre-service teachers' employees, teaching using the FCS has an impact on their mathematical thinking. Also, modern technology such as Learning Management System platforms has an effective role in saving time and effort.

\section{$4 \quad$ Recommendations and suggestions}

The researcher recommends the necessity of using the flipped classroom strategy through Learning Management Systems websites and educational platforms in teach- 
ing university students (pre-service teachers) in educational programs especially open education students. Because of the advantages of this strategy, such as its focus on the learner's activity, increasing his motivation, saving time and effort, and teaching using flipped classrooms provides a university educational environment that harnesses modern technology in education. The flipped classroom strategy helps students regardless of their characteristics such as the nature of work and the nature of previous training in the field of education, and the researcher suggests conducting other studies on students of secondary and basic stages and other specializations.

\section{$5 \quad$ References}

[1] Bergman, J., \& A., Sams, A. (2014). Flipped learning: Maximizing face time. Training \& Development, 68(2), 28-31.

[2] Pearson, G. (2013). Flipped learning in higher education. Retrieved September 5, 2016, from: http://flippedlearning.org/wp-content/uploads/2016/07/HigherEdWhitePaper-FINAL . $\mathrm{pdf}$

[3] Arab Open University. (2019). Curricula and general teaching method. AOU.

[4] William, S. (2018). Extending the principles of flipped learning to achieve measurable results: emerging research and opportunities. E-book, Hershey: IGI Global.

[5] NCTM. (2000). Principles and standards for school mathematics. Reston: NCTM.

[6] PISA.(2018). Program for international student assessment. https://www.oecd-ilibrary. org/education/pisa-2018-results-volume-i_5f07c754-en

[7] Najem, Kh. (2012). The Effect of a Training Program for the Development of Mathematical Thinking on the Achievement of the Seventh Grade Students in Mathematics , Damascus University Journal, 28 (2), 491-525.

[8] Bergman, J., \& Sams, A. (2012). Flip your Classroom Reach Every Student in Every Class Every Day. International Society for Technology in Education.

[9] Alahmadi, T. (2019). Effect of flip classrooms in development the promote and deferred of female students at college students in Aola and attitudes towards the strategy, International Journal for Psychological and Educational Studies, 6(3), 313-326.

[10] Petrovici, A., Nemesu, R. (2015). Flipped learning GeoGebra and wiris on Moodle Platform, or regiments in favor of integrating in education. The $11^{\text {th }}$ international Scientific Conference E-Learning and Software for Education. Bucharest.

[11] Algamdi, M., Anasari, W. (2018). The effectiveness of employing the flipped learning strategy in the development of self-learning skills and academic achievement in the social studies and national courses among the first level female students in the secondary stage in Taif city. International Journal for Research in Education, 42(3), 196-232.

[12] Bishop, J. \&Verleger, M. (2013, 23-26 June). The flipped classroom: A Survey of the Research. Paper presented at the 120th ASEE Annual Conference and Exposition, American Society for Engineering Education, Atlanta. https://doi.org/10.18260/1-2--22585

[13] Hamdan, N., McKnight, K., \& Afrstrom, K. (2013). The flipped learning model: A white paper based on the literature review titled a review of flipped learning. Flipped Learning Network. http://flippedlearning.org/wpcontent/uploads/2016/07/WhitePaper FlippedLearn ing.pdf Q4Q4

[14] Amber, M., Barbara, B., Michele, J. (2015). Learning designs using flipped classroom instruction. Canadian Journal of Learning and Technology, 41(2), 1-23. 
Paper-Impact of Using Flipped Classroom Strategy in Developing the Mathematical Thinking of...

[15] Olakanmi, E. (2017). The effects of a flipped classroom model of instruction on students' performance and attitudes towards chemistry. Journal of Science Education and Technology, 26(1), 127-137. https://doi.org/10.1007/s10956-016-9657-x

[16] Alhosneeh, H. (2015). Flipped classroom impact on the development of general selfcompetence and educational achievement among ninth graders in oman (Unpublished Master's Thesis). Sultan Qaboos University, Oman.

[17] Khalil, I. (2015). The impact of using the inverted grade strategy on the development of some components of self-organized learning and the trend towards subject in sixth grade students. https://www.researchgate.net/publication/304270120-bath-ajrayy-athr-astkhdam

[18] Aldowekh, N. (2014). Flip class room. Journal of Knowledge, 33, retrieved from: http:// www.almarefh.net/show_content_sub.php?CUV=428\&Model=M\&SubModel=216\&ID=2 $\underline{295 \& \text { ShowAll=On }}$

[19] DeGrazia, J. L., Falconer, J. L., Nicodemus, G., \& Medlin, W. (2012). Incorporating screencasts into chemical engineering courses. Paper presented at the ASEE Annual Conference \& Exposition, Atlanta, USA. https://doi.org/10.18260/1-2--18130

[20] Wagner, D., Laforge, P., \&Cripps, D. (2013, 17-20 June). Lecture Material Retention: A first trial report on flipped classroom strategies in electronic systems engineering at the University of Regina. (Paper) Canadian Engineering Education Association (CEEA13) conference, Montreal, Canada. https://doi.org/10.24908/pceea.v0i0.4804

[21] Mason, G., Shuman, T., \& Cook, K. (2013). Comparing the effectiveness of an inverted classroom to a traditional classroom in an upper-division Geometry course. IEEE Transactions on Education, 56(4), 430-435. https://doi.org/10.1109/te.2013.2249066

[22] Davies, R. Dean, D \& Ball, N (2013). Flipping the classroom instructional technology integration in a college level information systems spreadsheet course. Education Technology Research and Development, 61(4), 563-580. https://doi.org/10.1007/s11423-013-9305-6

[23] Butt, A. (2014). Student's view on the use of a flipped classroom approach: evidence from Australia. Business Education \& Accreditation, 6(1), 33-45.

[24] Hazaymeh, W., Altakhaineh, A. (2019). The effect of flipped classroom instruction on developing emirati efl learners' pragmatic competence. The International Journal of Learning, Teaching and Educational Research, 18(10), 89-111. https://doi.org/10.26803/ijlter.18 .10 .6

[25] Sabag, A., Asgool, M., Agel, M. (2021). The effectiveness of a proposed design model of a flipped classroom based on projects in developing educational software production skills for students of the Faculty of Education at the Islamic University of Gaza. IUG Journal of Educational and Psychology Studies, 29(2), 66-90.

[26] Dweikat, Kh. Raba, A. (2019). Perceptions of flipped classroom model in Palestine. IUG Journal of Educational and Psychology Studies, 27(3), 29-47.

[27] Roasa, T. (2018). The effectiveness of flipped classroom in teaching the science teaching strategies and its assessment course on the academic achievement and mind habits development of the student of princess norah bint abdulrahman university. IUG Journal of Educational and Psychology Studies, 26(1), 128-150. https://doi.org/10.12816/0048779

[28] Algaysi, T. (2014). The effect of using the Marazzano learning model on mathematical thinking and the attitude toward mathematics among basic stage students in Tafila governorate. Specialized International Journal, 12 (3), 234-250.

[29] Fernandez, B. (2003). The construction of mathematical thinking. University Center for Higher Education "Don Bosco," Madrid, Spain. International Congress Brain, Intelligence and Educational Programs. Early Childhood and Nursery Education. El Salvador. Retrieved from: http://www.waece.org/memoriascongresos/cong2003elsalvador/textos/fernan dezbravo.htm 
Paper-Impact of Using Flipped Classroom Strategy in Developing the Mathematical Thinking of...

[30] Ersoy, E., Ganer, P. (2015). Mathematics teaching and mathematics thinking, Journal of Research in Education and Teaching, 13(2), 102-110.

[31] Barham, A. \& Al-Khatib, M. (2012). Students' levels in the mathematical thinking skills for classroom teachers at the Hashemite University and its relation to their achievement in mathematics. Education Journal, 103(26), 277-312.

[32] Rizig, H. (2018). The effect of real learning in developing mathematical thinking skills for female students of the first stage in makkah al-mukarramah. Journal of the College of Education, 180, 355-384.

[33] Aprianto, E., Purwati, O., Anam, S. (2020). Multimedia-Assisted Learning in a Flipped Classroom: A Case Study of Autonomous Learning on EFL University Students, International journal of emerging technology in learning (i-jet),15(24),114-127. https://doi.org/ 10.3991/ijet.v15i24.14017

[34] Zaroug, M., Olivera, E., Khaldi, M.(2020), The Impact of Flipped Project-Based Learning on Self-Regulation in Higher Education, International journal of emerging technology in learning (i-jet), 15(17), 127-147. https://doi.org/10.3991/ijet.v15i17.14135

[35] Alsalhi, N., Eltahir, M., Al-Qatawneh,S.(2021). Blended Learning in Higher Education: A Study of Its Impact on Students' Performance, International journal of emerging technology in learning ( $i$-jet), 16(14), 249-268. https://doi.org/10.3991/ijet.v16i14.23775

[36] Obaid, W. (2004). Teaching mathematics to all children in light of the requirements of standards and a culture of change. Dar Al-Masirah for publishing and distribution.

[37] Strayer, J. (2012). How learning in an inverted classroom influences cooperation, innovation and task orientations. Learning Environ Res, 15, 171-193. https://doi.org/10.1007/s10 984-012-9108-4

\section{Author}

Dr Bahjat altakhayneh associate professor in curricula and mathematics instructions, in education department at the Arab Open University-Jordan.

Article submitted 2021-06-21. Resubmitted 2021-08-03. Final acceptance 2021-08-03. Final version published as submitted by the author. 